\title{
COMPOSICIÓN FISICOQUÍMICA DEL FRUTO DE DOS VARIEDADES DE DURAZNERO CULTIVADAS EN EL CENTRO-ESTE DE LA PROVINCIA DE SANTA FE
}

\author{
Bonazzola, C. ${ }^{1}$; Alsina, D. ${ }^{1}$; Nescier, I. de los M. ${ }^{1}$; \\ SAntini, Z.; Joris, Z. ${ }^{2} \&$ Gariglio, N. ${ }^{1}$
}

\begin{abstract}
RESUMEN
En la zona centro-este de la Provincia de Santa Fe desde hace un tiempo se comenzó a cultivar frutales, principalmente durazneros y cítricos, como una alternativa productiva. El objetivo de este trabajo fue evaluar los parámetros fisicoquímicos del jugo y la pulpa de duraznos de las cvs. 'Flordaking' y 'Forastero'. La variedad influyó significativamente en varios de los parámetros físico-químicos analizados. En el jugo, los valores de $\mathrm{pH}$ y conductividad eléctrica fueron significativamente menores en la cv. 'Flordaking', mientras que el contenido de sólidos solubles y la acidez titulable fue superior ( $3 \%$ y $12,8 \%$, respectivamente). El ratio de la cv. 'Forastero' fue significativamente superior. En la pulpa del fruto, el contenido de proteína y de fibra fueron significativamente mayores (9 y 20\%, respectivamente) en la cv. 'Flordaking'. Tanto la pulpa como el jugo de ambas variedades presentaron propiedades que las hacen aptas tanto para el consumo humano de fruta en fresco, o como materia prima para a elaboración de productos alternativos.
\end{abstract}

Palabras claves: Prunus persica, fisicoquímicos, calidad nutricional.

\section{SUMMARY}

\section{Physical-chemical composition of two peach variety fruits cultivated at the central-east area of the province of Santa Fe, Argentina.}

Peaches and Citrus fruit production is a new alternative activity at the central-east Region of the Santa Fe Province. The objective of this work was to evaluate fruit quality of 'Flordakiing' and 'Forastero' peach varieties by measuring the physicochemical and nutritional parameters of the juice and pulp. $\mathrm{pH}$ and electrical conductivity of the juice were significantly lower in the cv. 'Flordaking' than in 'Forastero', whereas solid soluble (SS) content and the titratable acidity were higher ( $3 \%$ and $12,8 \%$, respectively) in the former. 'Forastero' showed a significantly higher SS-titratable acidity ratio. In the other hand, protein and fiber content in the pulp of the fruit were significantly higher ( 9 and $20 \%$, respectively) in the cv. 'Flordaking' than in 'Forastero'. The physico-chemical characterization of the Juice and pulp of the two varieties, revealed its adaptation for it use both, for fresh consumption or for the elaboration of alternative food products.

Key words: Prunus Persica, Physical-chemical, Nutritional quality.

1.- Facultad de Ciencias Agrarias. Universidad Nacional del Litoral. Kreder 2805. (3080) Esperanza, provincia de Santa Fe. Email: cecibonazzola@yahoo.com.ar

2.- Facultad de Bioquímica y Cs. Biológicas (UNL).

Manuscrito recibido el 28 de diciembre de 2007 y aceptado para su publicación el 12 de junio de 2008. 